\title{
PEMBERDAYAAN MASYARAKAT DESA PIJOT MELALUI PENGOLAHAN IKAN MENJADI BAKSO DAN NUGGET
}

\author{
Novia Anggraeni ${ }^{1)}$, Hilalia ${ }^{2)}$, Muhamad $\mathrm{Ali}^{3)^{*}}$ \\ 1)Program Studi Akuntansi, Universitas Mataram \\ 2)Program Studi Hubungan Internasional, Universitas Mataram \\ 3)Program Studi Peternakan, Universitas Mataram \\ Jalan Majapahit, Nomor 62, Kota Mataram NTB \\ ${ }^{*}$ Alamat korespondensi:: m_ali@unram.ac.id
}

\begin{abstract}
ABSTRAK
Desa Pijot merupakan salah satu desa yang tergabung dalam BUMDesMa Sinar Bahari yang merupakan bimbingan dari Dinas Pemberdayaan Masyarakat dan Desa (PMD) Kabupaten Lombok Timur. Salah satu usaha yang dirintis oleh Bumdesma ini ialah pengolahan ikan berupa bakso, nugget, sosis dan pakan ikan. Hal tersebut telah didukung dengan ketersediaan gedung pabrik dan mesin yang telah dianggarkan oleh pemerintah pusat. Namun, yang menjadi kendala di desa ini ialah kurangnya pengetahuan masyarakat dalam mengoprasionalkan alat dan cara pengolahan ikan untuk menjadi produk yang diinginkan. Pelatihan pembuatan bakso dan nugget ikan bertujuan meningkatkan ketrampilan dan pengetahuan masyarakat untuk mengelola ikan sehinggan meningkatkan nilai jual dari ikan yang melimpah pada musim-musim tertentu. Kegiatan pegabdian kepada masyarakat ini bertujuan untuk meningkatkan kualitas sumber daya masyarakat Desa Pijot serta sumber daya alam yang dimiliki melalui pelatihan pengolahan ikan menjadi bakso dan nugget ikan. Dampak yang ingin dicapai ialah terciptanya masyarakat yang mampu mengelola sumber daya yang ada serta teroptimalisasikannya potensi Desa Pijot. Metode pengumpulan data yang digunakan adalah observasi dan wawancara sedangkan metode analisis menggunakan deskriptif kualitatif. Hasil yang telah dicapai dengan adanya program ini ialah bertambahnya pengetahuan masyarakat untuk mengoptimalkan sumberdaya ikan sehingga terciptanya produk olahan berupa bakso dan nugget yang berkualitas dan berdaya saing di pasaran.
\end{abstract}

Kata Kunci: bakso ikan, desa pijot, pengolahan ikan, nugget ikan 


\section{PENDAHULUAN}

Desa Pijot merupakan salah satu desa yang ada di Kecamatan Keruak Kabupaten Lombok Timur. Desa Pijot dihuni oleh masyarakat dengan mayoritas pekerjaan sebagai petani dan nelayan. Jumlah penduduk desa Pijot pada tahun 2015 sebanyak 6.113 jiwa dengan laki-laki sebanyak 3.042 jiwa dan wanita sebanyak 3.071 jiwa. Luas wilayah desa Pijot kurang lebih $\pm 715 \mathrm{Ha}$ dengan luas pemukiman penduduk sebesar $49 \mathrm{Ha}$. Desa Pijot terdiri dari 4 (empat) dusun yaitu dusun Pijot Selatan, Dusun Padak Selatan, Dusun Pemban, danDusun Larangan. Potensi unggulan desa Pijot bergerak pada bidang pertanian secara luas terutama hasil laut dan pariwisata (BPS, 2016).

Saat ini yang menjadi fokus utama Desa Pijot adalah pengolahan ikan menjadi aneka ragam makanan seperti bakso dan nugget ikan berbasis zero waste. Produksi ini dikategorikan sebagai kegiatan berbasis zero waste sebab masyarakat tidak hanya diajarkan untuk mengolah daging ikan, melainkan pengolahan limbahnya yang berupa kepala ikan, tulang dan bagian ikan lainnya yang tidak diolah sebagai bakso ikan dan nugget ikan dapat dimanfaatkan dan menambah nilai jual dari limbah tersebut dengan cara mengolahnya menjadi pakan ikan (Pelet Ikan). Berdasarkan hasil observasi dan wawancara yang dilakukan kepada kepala desa Pijot, kami menemukan bahwa mesin untuk pengolahan ikan dan limbahnya sebagai pakan ikan sudah disediakan oleh desa. Namun, yang menjadi permasalahan utama dalam pengolahan ikan ini ialah masih kurangnya kualitas sumberdaya manusia untuk mengoperasikan mesin tersebut untuk memperoleh produk yang diinginkan dan Penyertaan Modal dari Tiga Desa yang tergabung dalam BUMDesMa yang belum terkumpul.

Melihat potensi yang ada di Desa Pijot dengan banyaknya ketersediaan ikan serta sarana dan prasarana pendukung seperti mesin maupun tenaga kerja serta mitra kerja, tim pelaksana kegiatan pengabdian kepada masyarakat ini mengajukan beberapa program kerja untuk membantu mengatasi permasalahan tersebut. Program yang diajukan disusun dengan mempertimbangkan faktor-faktor yang mendukung pengolahan setelah melalui observasi dan wawancara dengan aparat setempat Wikandari et.al., 2016).

Diharapkan melalui program yang kami usulkan dapat menambah keterampilan masyarakat untuk mengolah ikan yang melimpah pada masa-masa tertentu yang biasa disebut oleh masyarakat setempat sebagai Masa Panen Ikan. Warsiki et.al., (2013) menyatakan bahwa 
perubahan bentuk dari daging segar menjadi produk olahan dapat meningkatkan usia simpan suatu produk makanan. Pada masa-masa tersebut, harga jual ikan anjlok (sangat murah) dan dengan melimpahnya ikan dipasaran menyebabkan banyaknya ikan yang terbuang sia-sia karena busuk dan otomatis menyebabkan nelayan dan pedagang ikan merugi. Pengolahan diharapkan dapat meningkatkan nilai tambah ikan tersebut sehingga dapat meningkatkan taraf perekonomian masyarakat.

\section{METODE KEGIATAN}

Kegiatan dilakukan selama 2 minggu yakni mulai pada tanggal 17 31 Agustus di Desa Pijot, Kecamatan Keruak, Kabupaten Lombok Timur, NTB.

\section{Alat dan Bahan}

Alat yang digunakan dalam program pelatihan pembuatan bakso dan nugget ikan adalah baskom,sendok,food processor, wajan, spatula, tirisan, kompor. Sedangkan bahan yang digunakan adalah daging ikan, tepung tapioka, garam, gula, bawang putih, msg, air es, dan minyak sayur. Namun, terdapat beberapa bahan yang ditambahkan pada olahan nugget seperti daun bawang, tepung roti dan bawang bombay.

\section{Prosedur Kerja Program}

Pelatihan Produksi Bakso dan Nugget Ikan

Prosedur kerja program produksi bakso dan nugget ikan: 1) Beraudiensi dengan pihak dinas kelautan dan perikanan sebagai pemateri 2) Membersihkan alat dan lokasi 3) Mempersiapkan bahan 4) Pembukaan kegiatan pelatihan 5) Pelatihan pembuatan bakso ikan, nugget ikan, pengemasan dan pemasaran 6) evaluasi kegiatan (Ernawaty dan Ismayani, 2018).

\section{Bentuk Kegiatan}

Bentuk kegiatan secara keseluruhan ini adalah 1) Persiapan program 2) Persiapan bahan 3) Pembukaan kegiatan 4) Pelatihan pembuatan bakso ikan, nugget ikan, pengemasan dan pemasaran 5) Produksi tahap kedua 6) Pengecekan kualitas produk.

\section{Metode Pengumpulan dan} Analisis Data

Metode pengumpulan data pada program ini adalah dengan metode survey, dengan teknik pegambilan data observasi secara langsung, wawancara dan studi pustaka. Metode analisis yang digunakan adalah deskriptif kualitatif.

\section{HASIL DAN PEMBAHASAN}

Program ini telah dilaksanakan secara terstruktur 
dengan melibatkan masyarakat secara aktif.

\begin{tabular}{|c|c|c|}
\hline Pelaksanaan & & Pelatihan \\
\hline $\begin{array}{l}\text { Pembuatan } \\
\text { Bakso Ikan }\end{array}$ & Nugget & ikan da \\
\hline Progra & & pelatiha \\
\hline pembuatan & nugget & dan $b$ \\
\hline & limulai & denga \\
\hline
\end{tabular}

dan pembersihan lokasi serta alat. Proses wawancara dilakukan dengan pihak kepala Desa Pijot dengan tujuan untuk mengetahui potensi yang dimiliki oleh desa serta proses pemberdayaan apa saja yang telah dilakukan oleh masyarakat setempat untuk mengoptimalkan potensi tersebut.

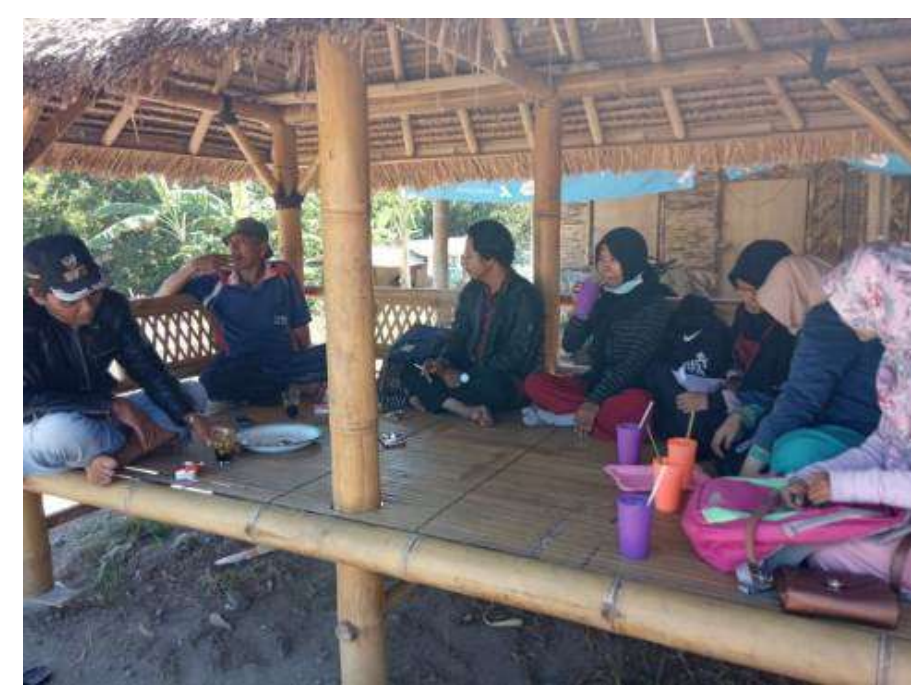

Gambar 1. Wawancara dengan kepala Desa Pijot terkait potensi desa.

Berdasarkan pada hasi
wawancara dan observasi
terdapat beberapa hal yang
ditemukan antaranya adalah:

1) Adanya BUMDesMart yang menaungi 3 desa yakni Pijot, Ketapang Raya dan Tanjung Luar. Dalam BUMDesMa tersebut ketiga desa bekerja sama untuk mengoptimalkan potensi yang dimilikinya, salah satu cara yang dilakukan ialah dengan menciptakan produk berbahan dasar ikan untuk meningkatkan pendapatan masyarakat.
Dalam menjalankan program tersebut setiap desa memiliki peran diantaranya ialah Tanjung Luar sebagai pensuplay ikan, Pijot sebagai lokasi pengolahan dan pemasaran, dan Ketapang Raya juga sebagai lokasi pemasaran.

2) Tersedianya mesin pembuat bakso, nugget, pemisah tulang, mesin pendingin, genset, mesin pembuat pelet dan pencacah daging yang telah dianggarkan oleh pemerintah pusat sebagai bentuk dukungan kerjasama antar desa. 


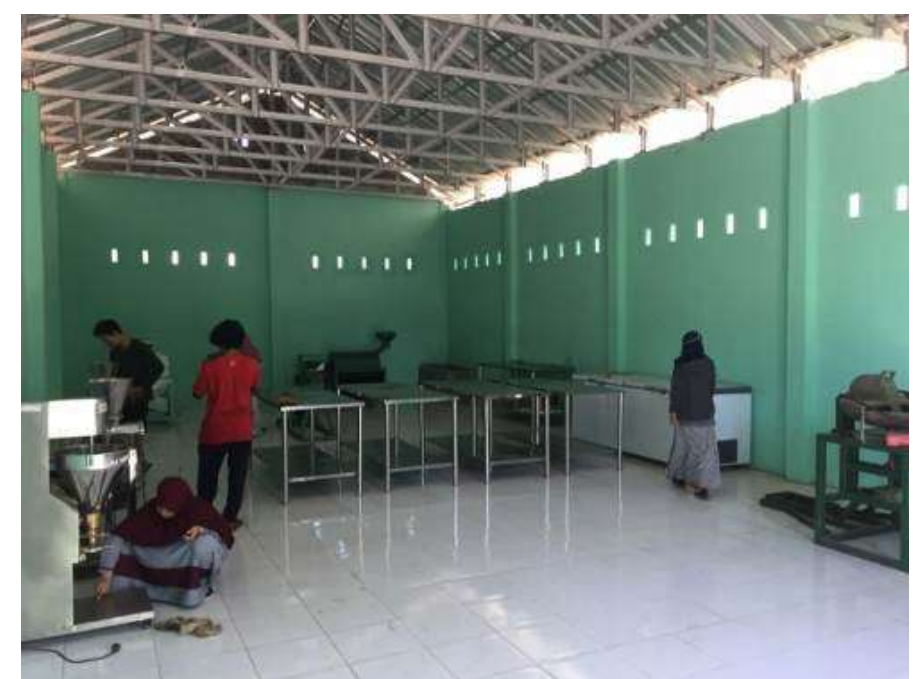

Gambar 2. Bantuan mesin yang dianggarkan oleh pemerintah Pusat.

Namun, dukungan berupa penyediaan teknologi tidak lantas mengakibatkan usaha yang diharapkan dapat berjalan sesuai dengan keinginan tiga desa tersebut. Hal ini diakibatkan karena beberapa hal diantaranya ialah: 1) Kurangnya sumber daya manusia yang dapat mengoperasikan mesin yang ada 3) Sulitnya akses untuk ke lokasi pabrik 4) Kondisi pabrik yang belum memadai untuk dilakukannya pengolahan. Selanjutnya pada persiapan program ialah pembersihan lokasi dan alat.

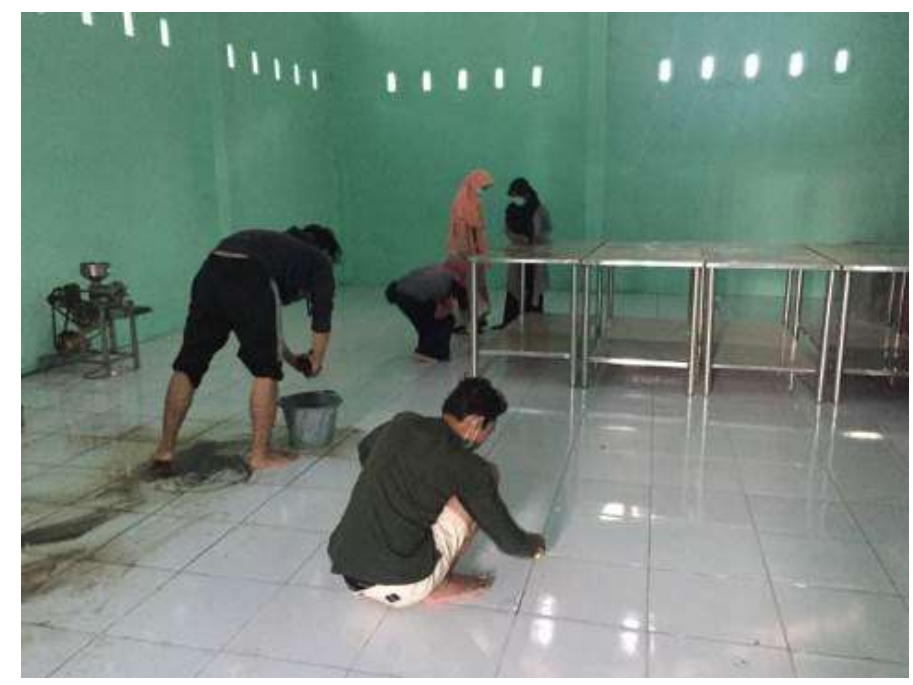

Gambar 3. Membersihkan pabrik

Proses membersihkan alat tersebut dilakukan dengan ditujukan untuk mensterilkan menggunakan sunlight dan cairan mesin dari kuman. Proses cuka. Cairan cuka berfungsi untuk 
menghilangkan karat yang ialah: 1) Daging Ikan 2) Tepung menempel pada bagian dalam tapioka 3) Garam 4) Gula 5) mesin, kemudian sunlight untuk Bawang putih 6) MSG 7) Air es. menghilangkan bau yang Sedangkan bahan untuk kegiatan ditimbulkan oleh cairan cuka dan untuk pembuatan nugget ikan untuk mengurangi bakteri yang adalah 1) Daging Ikan 2) Tepung menempel pada mesin.

Tahap kedua ialah tapioca 3) Garam 4) Daun bawang 5) Bawang Bombay 6) Bawang persiapan bahan. Bahan-bahan yang disediakan dalam proses putih 7) MSG 8) Air es 9) Minyak pelatihan pembuatan bakso ikan sayur 10) Tepung panir.

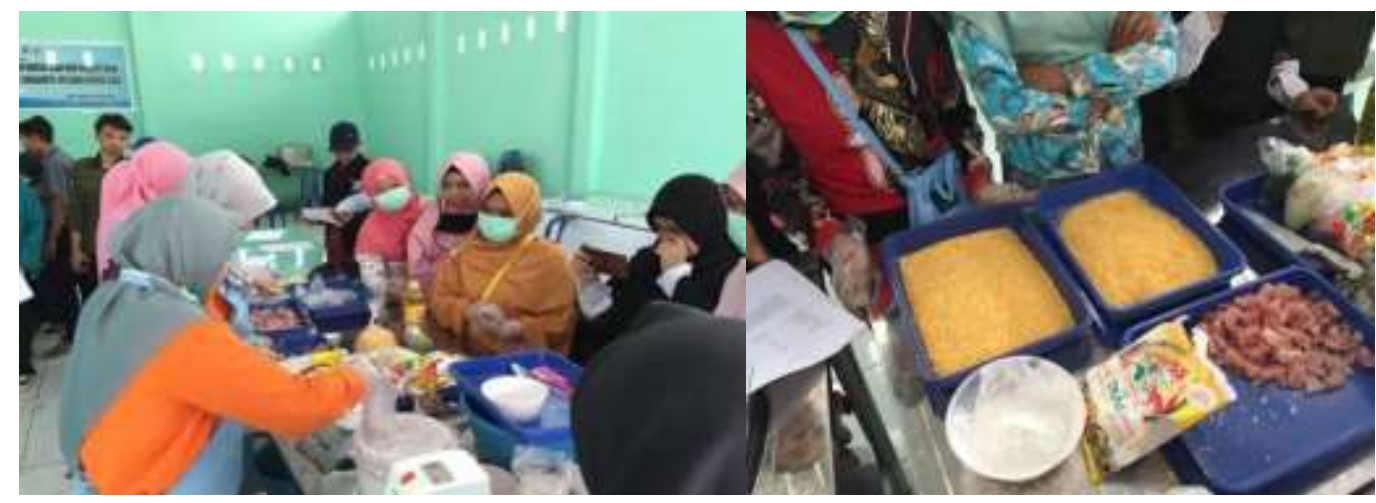

Gambar 5. Bahan bakso dan nugget ikan

Dalam pembuatan produk ini, semua bahan kecuali ikan telah di suplay oleh toko BUMDesMa Sinar Bahari sedangkan ikannya diambil dari Tanjung Luar. Tahap ketiga pada kegiatan ini adalah pembukaan pelatihan. Pelatihan ini menghadirkan beberapa pihak diantaranya adalah kepala desa dari tiga desa, ketua BUMDesMa, Camat, Dinas Perikanan dan Kelautan Provinsi Nusa Tenggara Barat, Dinas Perikanan dan Kelautan Kabupaten Lombok Timur, masyarakat dari ketiga desa yang sudah direkrut sebagai pekerja, dan beberapa masyarakat lainnya. 


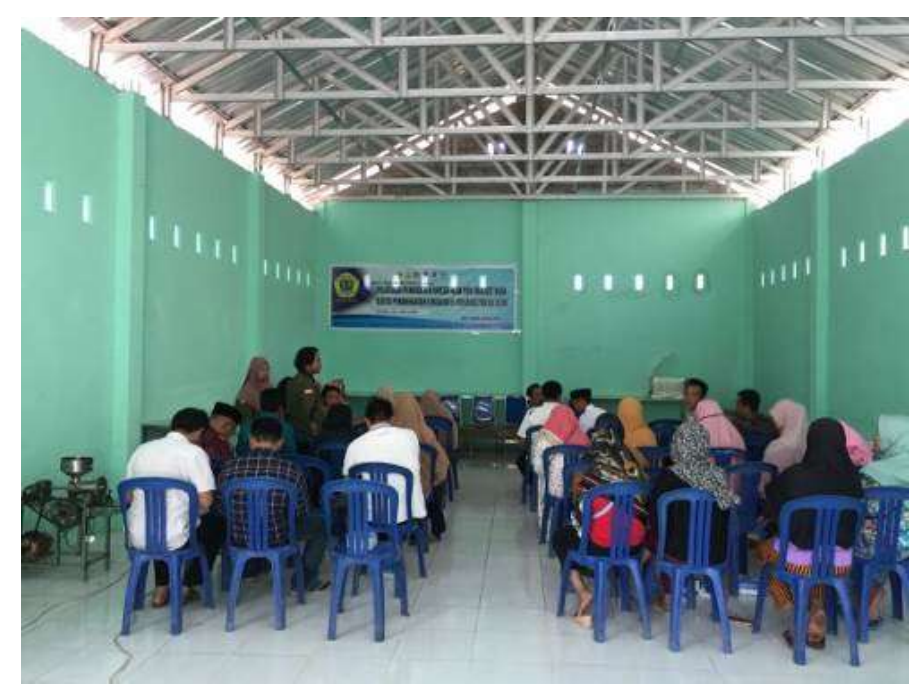

Gambar 6. Pelatihan Pembukuan Sederhana

\begin{tabular}{cll}
\multicolumn{2}{r}{ Pelatihan pembuatan } & bakso atau nugget besar lainnya. \\
bakso ikan dan nugget ikan & Tekstur bakso dan nugget \\
diawali dengan penyampaian & tersebut didapatkan dengan \\
materi pengantar oleh pemateri. & mencampurkan es batu dan \\
Dilanjutkan dengan praktik & garam dapur saat penggilingan \\
langsung yang melibatkan seluruh & daging ikan (Sarofa, 2014). \\
peserta pelatihan. & Penggunaan ikan berdaging putih \\
Gambar 7: Proses pembuatan & juga merupakan salah satu \\
bakso ikan & penyebab didapatkannya tekstur \\
Hasil pelatihan ini adalah & bakso dan nugget yang kenyal dan \\
produk bakso ikan dengan tekstur & lezat tersebut.
\end{tabular}
kenyal dan lezat serta nugget ikan yang sedap dengan kualitas yang tidak kalah dengan hasil pabrik

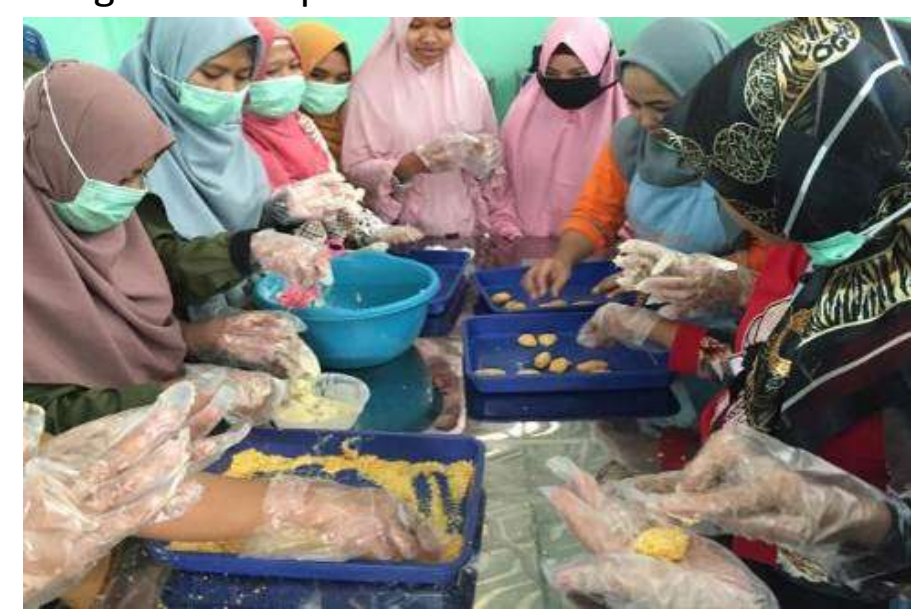

Gambar 7. Proses pembuatan nugget ikan 
Hasil pelatihan ini adalah garam dapur saat penggilingan produk bakso ikan dengan tekstur daging ikan. Penggunaan ikan kenyal dan lezat serta nugget ikan berdaging putih merupakan salah yang sedap dengan kualitas yang satu penyebab didapatkannya tidak kalah dengan hasil pabrik tekstur bakso dan nugget yang bakso atau nugget besar lainnya. kenyal dan lezat (Poernomo et.al., Tekstur bakso dan nugget 2013) tersebut didapatkan dengan mencampurkan es batu dan

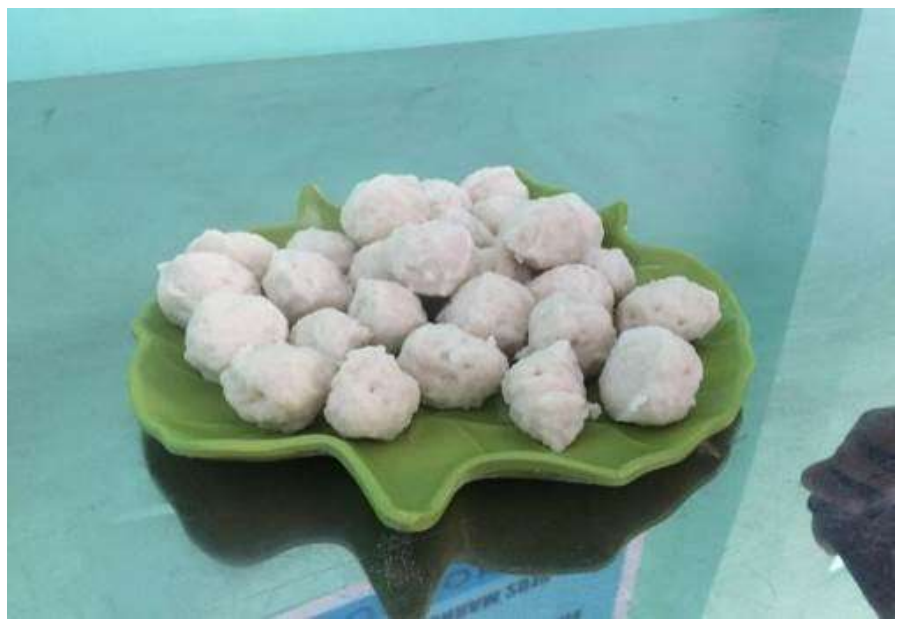

Gambar 8. Bakso ikan siap saji

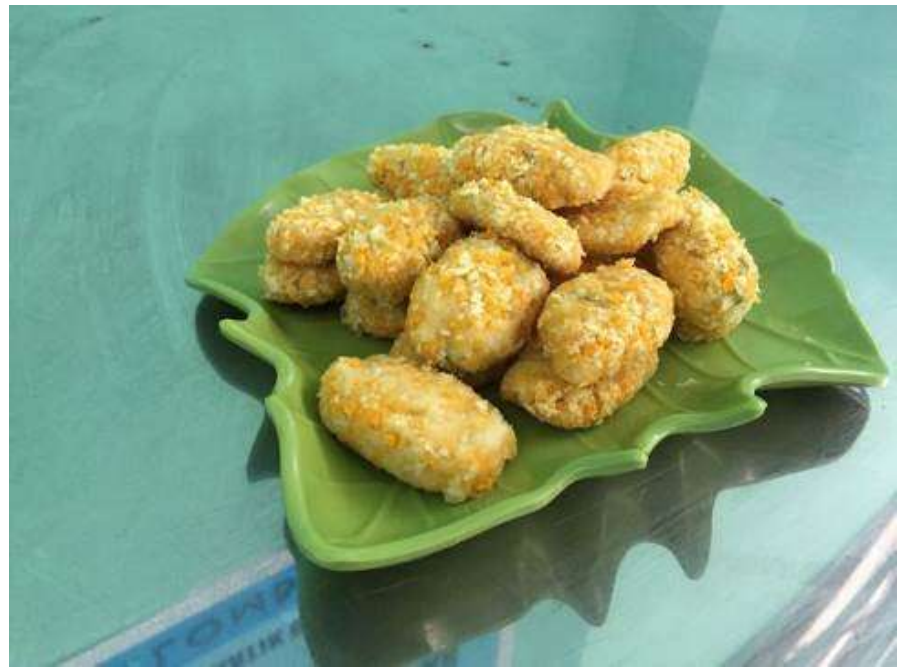

Gambar 9. Nugget ikan siap saji

Kemudian dilakukan adalah 250gr dan 300gr. pengemasan kedalam wadah Ditempelkan stiker yang memuat dengan berat masing-masing informasi produk.

Bakso Ikan dan Nugget Ikan 


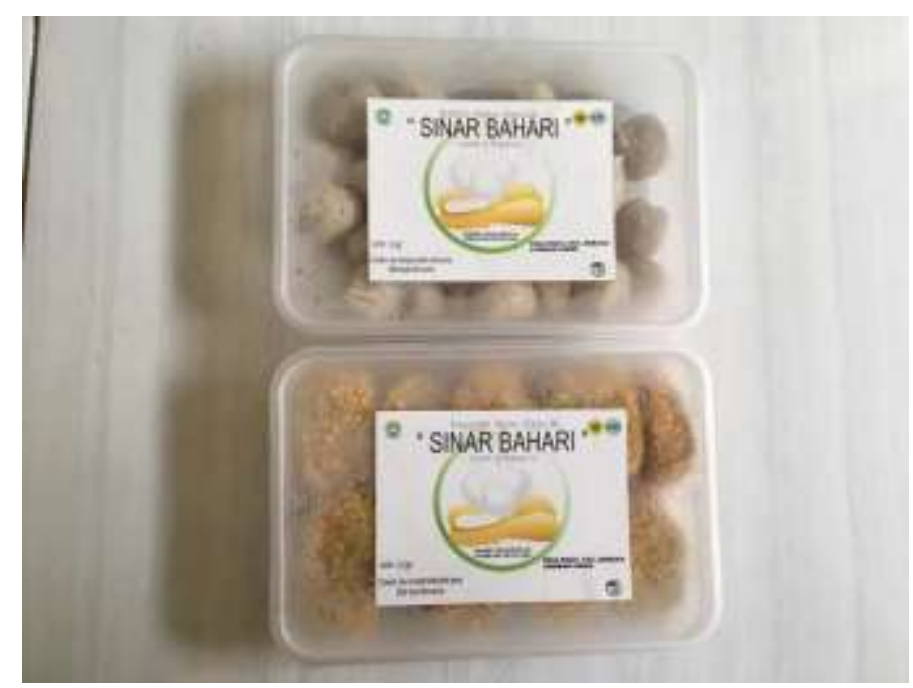

Gambar 10. Bakso dan nugget yang telah dikemas

Dilanjutkan dengan Dinas Kelautan dan Perikanan bimbingan manajemen pemasaran Provinsi NTB. yang disampaikan oleh pemateri dari

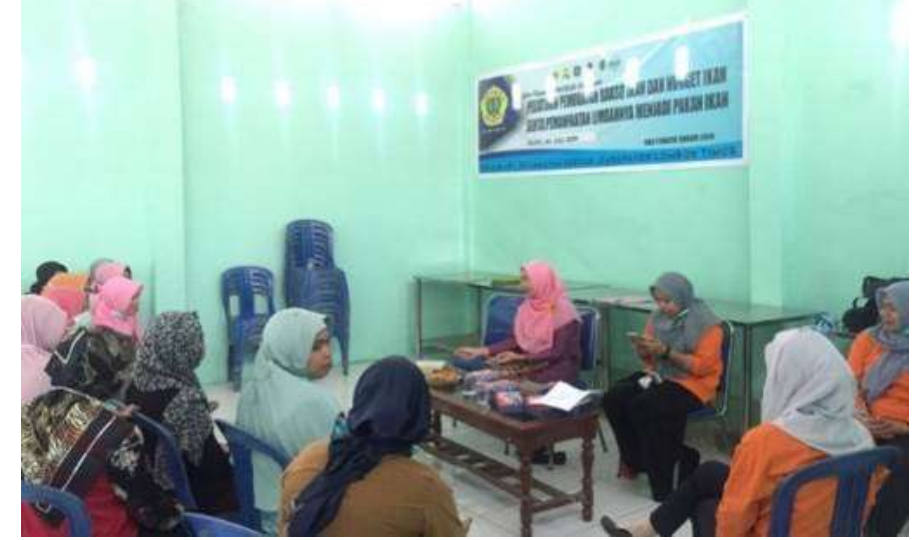

Gambar 11. Penyampaian materi mengenai pemasaran produk

\section{KESIMPULAN}

Kesimpulan dari kegiatan pengabdian kepada masyarakat ini adalah meningkatnya kualitas sumberdaya alam masyarakat Desa Pijot melalui pengolahan ikan menjadi bentuk bakso dan nugget.

\section{UCAPAN TERIMA KASIH}

Terima kasih penulis ucapkan kepada semua pihak yang turut menyumbangkan keringat dan ide dalam kegiatan yang telah diselenggarakan oleh Mahasiswa KKN Universitas Mataram periode 2019, antara lain; Dinas Kelautan dan Perikanan Provinsi Nusa Tenggara Barat, Dinas Pemberdayaan 
Masyarakat dan Desa Kabupaten Lombok Timur, Kepala Desa Pijot, Pengurus BUMDesMar Desa Pijot.

\section{DAFTAR PUSTAKA}

Warsiki E, Sunarti TC, Nurmala L. 2013. Kemasan Anti mikrob untuk Memperpanjang Umur Simpan Bakso Ikan. Jurnal IImu Pertanian Indonesia (JIPI). 18 (2). 125-131.

BPS. 2016. NTB Dalam Angka. Badan

Pusat Statistik Provinsi Nusa

Tenggara Barat.

Poernomo D, Suseno SH, dan Subekti BP. 2013. Karakteristik Fisika Kimia Bakso Dari Daging Lumat Ikan Layaran. JPHPI. 16(1). 58-68.

Sarofa U, Sudaryati HP, Syaiful. 2014. Evaluasi Kualitas Kamaboko Ikan Manyung (Arius thalassinus) dengan Variasi

Penggunaan Tapioka dan $\mathrm{NaCl}$. Jurnal Rekapang. 8 (1). 50-57.

Ernawaty I, Ismayani. 2018. The Development Strategy of Fish Processing Industry In Banda Aceh. Russian Journal of Agricultural \& Socio Economic Science. 79 (7). 357-364.

Wikandari PR, Rusmini, Wati NK, Adhiprahara M. 2016. Pelatihan Pembuatan Produk Ikan Olahan di Desa Candi tunggal-Kalitengah Lamongan. Vol. 1, No. 1, Juni 2015, hal. $40-46$. 